\title{
Uso da Uréia como Suplemento Protéico na Dieta de Doadoras e Receptoras de Embriões Bovinos
}

\author{
Amílcar Gasperin Barreto ${ }^{1}$, Hélder Louvandini ${ }^{2}$, Celso de Paula Costa ${ }^{3}$, Concepta McManus ${ }^{4}$, \\ Rodolfo Rumpf ${ }^{5}$
}

\begin{abstract}
RESUMO - Doze doadoras de embriões Bos indicus da raça Nelore foram confinadas recebendo $25 \mathrm{~kg}$ de silagem de milho e $2,5 \mathrm{~kg}$ de três diferentes suplementos concentrados ao dia. O ingrediente protéico ofertado foi SOJA (S), SOJA+URÉIA (S+U) e URÉIA (U). Após período de 20 dias, as doadoras foram superovuladas e seus embriões colhidos e cultivados in vitro até eclosão. Não se observou diferença entre tratamentos com relação ao número total de estruturas colhidas $(4,17 ; 8,42$ e 7,00$)$, número de embriões viáveis $(2,25$; 3,50 e 4,33), de ovócitos $(1,42 ; 3,92$ e 1,08) ou de estruturas degeneradas $(0,5 ; 1,0$ e 1,83), bem como na taxa de eclosão in vitro (81,48\%; $78,57 \%$ e $84,62 \%$ ) nos grupos S, S+U e U, respectivamente. As 66 receptoras de embriões foram mantidas em pasto de Braquiaria decumbens com 1,25 kg de suplemento concentrado dividido em três tratamentos semelhantes aos recebidos pelas doadoras. Após 37 dias, embriões foram descongelados e transferidos em grupos S, S+U e U. Não se observaram diferenças na taxa de gestação aos 30 dias $(25 ; 28$ e $28,57 \%)$ e aos 60 dias $(16,67 ; 28$ e $25 \%)$, nos grupos S, S+U e U, respectivamente. Tendo em vista que não foi observado efeito deletério na qualidade dos embriões, taxa de eclosão e fertilidade das receptoras, pode-se concluir que a uréia se mostrou como uma opção na substituição do farelo de soja em concentrados na suplementação de doadoras e receptoras de embriões.
\end{abstract}

Palavras-chave: bovino, embrião, proteína, suplemento, transferência, uréia

\section{Urea as a Protein Supplementation in the Diet of Bovine Embryo Donors and Recipients}

ABSTRACT - Twelve Bos indicus (Nellore) embryo donors were confined receiving $25 \mathrm{~kg}$ maize silage and $2.5 \mathrm{~kg}$ concentrate supplement per day. The proteic supplements used were SOYA (S), SOYA+UREA (S+U) and UREA (U). After 20 day, embryo donors were superovulated and their embryos collected and cultivated in vitro until eclosion. There was no significant statistical difference between the three groups in total number of structures collected (4.17, 8.42 and 7.00), number of viable embryos (2.25, 3.50 and 4.33), oocytes $(1.42,3.92$ and 1.08$)$ or degenerated embryos $(0.5,1.0$ and 1.83$)$, as well as in vitro eclosion rate $(81.48,78.57$ and $84.62 \%)$, for the groups $\mathrm{S}, \mathrm{S}+\mathrm{U}$ and $\mathrm{U}$, respectively. The 66 recipients were kept on Braquiaria decumbens pasture with $1.25 \mathrm{~kg}$ of concentrate supplements for the S, S+U and U groups. Frozen embryos were thawed and transferred after 37 days. There was no significant statistical difference in pregnancy rates at 30 days $(25,28$ and $28.57 \%)$, and 60 days of pregnancy $(16.67,28$ and $25 \%)$. It may be concluded that urea can replace the soybean meal in concentrated rations for supplementation of bovine embryo donors and recipients since there were no negative effects in embryo quality, eclosion rate and recipient fertility.

Key Words: bovine, embryo, protein, supplementation, transfer, urea

\section{Introdução}

No Brasil Central existem duas estações climáticas bem definidas. De outubro a abril as chuvas são abundantes (estação das águas) e de maio a setembro praticamente não ocorre precipitação pluviométrica (estação seca). Quase todos os volumosos usados para suplementação durante esta época são deficientes em proteína. A uréia é o suplemento protéico mais utilizado na estação seca do Brasil Central, entretanto, tem sido pouco utilizada em programas de transferência de embriões (TE).

Suplementos com uréia aumentam sensivelmente a síntese de proteína microbiana em animais alimentados com feno de pastagens maduras, principalmente quando associados a fontes de energia facilmente metabolizáveis (Dixon \& Doyle, 1996). Entretanto, seu uso tem sido associado com problemas de fertilidade.

Garcia-Bojalil et al. (1994), usando dietas com 12,3 e $27,4 \%$ de $\mathrm{PB}$, não observaram redução na

\footnotetext{
1 Mestrando da UnB, Fac.de Agronomia e Med.Veterinária. E.mail: amilcargb@tba.com.br

2 Professor, UnB, Fac. de Agronomia e Med. Veterinária. E.mail: hlouvand@unb.br , Campus Universitário Darcy Ribeiro Faculdade de Agronomia e Medicina Veterinária Caixa Postal 04508, Brasília DF 70910-900

3 Técnico, Integral Nutrição Animal, Goiânia.

4 Professora, UnB, Fac. de Agronomia e Med. Veterinária. E.mail: concepta@unb.br

5 Pesquisador, Embrapa Cenargen, Brasília - DF. E.mail: rumpf@cenargen.embrapa.br
} 
qualidade ou no número de embriões viáveis de vacas superovuladas. Elrod et al. (1993) verificaram pH uterino mais baixo nos animais que receberam excesso de proteína, quando comparados com o controle, independentemente deste excesso ser devido a proteína degradável ou não degradável no rúmen, o que leva a crer que a causa dos problemas reprodutivos poderia ser apenas o excesso de proteína e não sua degradabilidade ruminal. $\mathrm{O}$ pH uterino e a uréia plasmática são inversamente correlacionados, de modo que quanto maior a concentração de uréia plasmática, menor será o $\mathrm{pH}$ uterino.

Níveis de uréia plasmática maiores que $20 \mathrm{mg} / 100$ $\mathrm{mL}$ foram associados à redução na taxa de concepção (Ferguson et al., 1991, 1993). Em doadoras de embriões a uréia no sangue era mais alta $(\mathrm{P}<0,01)$ nos animais produzindo menos de três embriões viáveis por colheita, que naqueles produzindo mais de seis (Humblot et al., 1998). Outros trabalhos, porém, não comprovaram estes achados (Carroll et al., 1988; Andrade et al., 1992; Garcia-Bojalil et al., 1994).

Dietas hiperprotêicas têm comprovada ação tóxica sobre o metabolismo dos espermatozóides, óvulos e embriões (Dasgupta et al., 1971; Bishonga et al., 1996). Os níveis plasmáticos de uréia, $\mathrm{P}, \mathrm{K}$ e Zn, e os níveis sangüíneos de amônia se alteram, ocasionando menor taxa de concepção (Jordan et al., 1983; Elrod \& Butler, 1993; Elrod et al., 1993). O fluído uterino não demonstra variação de $\mathrm{pH}$ no dia do cio, porém apresenta queda significativa de $\mathrm{pH}$ no $7^{\circ}$ dia após o cio (Elrod et al., 1993), o que possivelmente ocorre pelo efeito anabólico do estradiol presente em maior concentração no período do cio do que no $7^{\circ}$ dia, provocando maior retenção de nitrogênio e redução da uréia plasmática.

Da mesma forma, animais em crescimento, como novilhas, têm maior quantidade de hormônio do crescimento (GH) circulante (Enright et al., 1990) e portanto maior poder anabólico que vacas adultas. $\mathrm{O}$ fluído uterino também apresenta alterações em $\mathrm{P}, \mathrm{K}$, $\mathrm{Mg}, \mathrm{Zn}$ e uréia, quando o animal recebe dietas hiperprotêicas (Jordan et al., 1983). Portanto, a citada queda da fertilidade provocada por dietas hiperprotêicas deve-se provavelmente a alterações no ambiente uterino (Canfield et al., 1990).

Bishonga et al. (1994) mostraram que ovelhas superovuladas recebendo dietas controle, com baixa $(15 \mathrm{~g} / \mathrm{kg})$ e com alto nivel de uréia $(30 \mathrm{~g} / \mathrm{kg})$ não apresentaram diferenças no número de ovulações. Entretanto, o número de estruturas recuperadas em relação ao número de ovulações foi de 50,$1 ; 40,0$ e $24,7 \%$ respectivamente, a porcentagem de embriões viáveis quatro dias após o cio foi de 80,66 e $25 \%$; o número de viáveis após 72 horas de cultivo foi de 70, 66 e $0 \%$ e a taxa de prenhez após autotransferência foi de $75,71,33 \%$, apresentando diferença $(\mathrm{P}<0,05)$. Os autores concluíram que a dieta, com alta concentração de proteína degradável no rúmen, prejudicou o desenvolvimento inicial e a sobrevivência dos embriões ovinos.

Também foi possível observar no grupo recebendo alta concentração de uréia que apenas $24,7 \%$ das ovulações tiveram suas estruturas recuperadas, 0 que pode ter ocorrido por problemas de motilidade no oviduto. Segundo Stalheim \& Gallagher (1977), o oviduto apresenta redução substancial de sua motilidade e do número de cílios quando cultivado em meio com elevada presença de amônia.

Shimbayashi \& Obara (1988) demonstraram que as enzimas hepáticas do ciclo da uréia, como a carbamoil fosfato sintetase, ornitina carbamoil transferase, arginina sintetase e arginase, entre outras, têm suas atividades aumentadas quando em presença de dietas com alta concentração protéica. Da mesma forma, em presença de vitamina E, as enzimas carbamoil fosfato sintetase e ornitina carbamoil transferase têm suas atividades aumentadas, potencializando a detoxificação da amônia.

O objetivo do trabalho foi verificar o efeito do teor de uréia na dieta sobre a resposta superovulatória e qualidade embrionária em doadoras e sobre a fertilidade pós-inovulação em receptoras de embriões bovinos na estação seca na região do Brasil Central, gerando informações capazes de reduzir os custos nos programas de transferência de embriões, pela utilização da uréia na alimentação dos animais.

\section{Material e Métodos}

\section{Experimento I: Uréia na alimentação de doado- ras de embriões}

Foram usadas como doadoras de embriões 12 vacas multíparas Bos taurus indicus da raça Nelore não-lactantes, com mais de cinco anos de idade e mínimo de dois partos. As doadoras foram divididas ao acaso em três grupos de quatro animais recebendo diferentes fontes de proteína no concentrado.

Após cada período de colheita dos embriões havia o rodízio dos animais nos tratamentos. A dieta foi ofertada às $8 \mathrm{~h} 30$ e $16 \mathrm{~h} 30$. Todos os grupos tiveram livre acesso a $25 \mathrm{~kg}$ de silagem de milho por cabeça/ 
dia como único volumoso, no qual foi acrescentado o concentrado. O grupo S tinha como suplemento protéico o farelo de soja a um custo de R $\$ 0,41$ ou US\$ 0,22 por $\mathrm{kg}$ de suplemento (US\$ $1,0=\mathrm{R} \$ 1,85$ ). $\mathrm{O}$ grupo $\mathrm{S}+\mathrm{U}$ teve a metade de sua proteína fornecida pelo farelo de soja e o restante substituído por uréia $(62,5 \mathrm{~g})$ a um custo de R $\$ 0,31$ ou US $\$ 0,17$ por $\mathrm{kg}$ de suplemento, e o grupo U possuía apenas uréia $(125 \mathrm{~g})$ como fonte protéica a um custo de R $\$ 0,27$ ou US\$ 0,15 por $\mathrm{kg}$ de suplemento.

Todos os concentrados foram isocalóricos, porém variáveis na fonte de sua proteína, com um volume de ingestão de $2,5 \mathrm{~kg} /$ cabeça/dia ao fim do período de adaptação de 10 dias. A composição do suplemento concentrado, seus níveis de garantia e a composição do sal mineral usados estão indicados nas Tabelas 1 a 3. A formulação foi efetuada de acordo com as exigências fornecidas pelo NRC (1996) para animais com peso médio de $398 \mathrm{~kg}$, consumo de matéria seca de $2,15 \%$ do peso vivo e para um ganho de peso de $453 \mathrm{~g} /$ dia.

Os cios foram observados todos os dias, duas vezes ao dia, sempre nos horários de fornecimento da alimentação. Na superovulação foi usada a dose de 250 UI de hormônio folículo estimulante, FSH (Pluset ${ }^{\circledR}$, Calier), em doses decrescentes por quatro dias. Uma dose de $150 \mu \mathrm{g}$ de cloprostenol foi aplicada na manhã e na tarde do terceiro dia de superovulação. Observado o cio, procedeu-se a inseminação artificial 12 e 24 horas após seu início, com sêmen de uma mesma partida. As colheitas foram feitas sete dias após o cio e os embriões foram avaliados e colocados em cultivo in vitro. No dia seguinte às colheitas, as doadoras tinham suas dietas modificadas e iniciavam novo período de adaptação.

Os embriões colhidos foram avaliados usando duas metodologias:

a) Morfológica:

De acordo com sua morfologia, as estruturas colhidas foram divididas em embriões viáveis, não fecundados (óvulos) e embriões degenerados. A classificação dos embriões obedeceu às normas da Sociedade Internacional de Tecnologia de Embriões (Stringfellow \& Seidel, 1999).

b) Viabilidade em cultivo in vitro:

Os embriões foram cultivados in vitro, por 48 horas, em meio de sais de Earle com antibióticos e soro fetal bovino em estufa de $\mathrm{CO}_{2}$ a $5 \%, 100 \%$ de umidade e a $38,5^{\circ} \mathrm{C}$. Ao final, foi feita nova análise para avaliar a taxa de eclosão dos mesmos.
Experimento II: Uréia na alimentação de receptoras de embriões

Sessenta e seis vacas multíparas, azebuadas (grau de sangue zebu maior que $75 \%$ ), com idade entre seis e 15 anos, com histórico de boa fertilidade e não

Tabela 1 - Composição dos três suplementos concentrados usados nas dietas das doadoras de embriões

Table 1 - Concentrate supplement composition used in embryo donors diets

\begin{tabular}{|c|c|c|c|}
\hline $\begin{array}{l}\text { Ingrediente } \\
\text { Ingredient } \\
\end{array}$ & $\begin{array}{l}\text { Soja } \\
\text { Soya }\end{array}$ & $\begin{array}{l}\text { Soja+Uréia } \\
\text { Soya+Urea }\end{array}$ & $\begin{array}{r}\text { Uréia } \\
\text { Urea } \\
\end{array}$ \\
\hline Farelo de soja (\%) & 38,00 & 19,00 & 0,00 \\
\hline $\begin{array}{l}\text { Soybean meal } \\
\text { Uréia pecuária (\%) }\end{array}$ & 0,00 & 2,50 & 5,00 \\
\hline $\begin{array}{l}\text { Urea } \\
\text { Milho integral moído(\%) }\end{array}$ & 50,00 & 67,50 & 85,00 \\
\hline $\begin{array}{l}\text { Milled maize } \\
\text { Caulim }(\%) \\
\text { Clay }\end{array}$ & 4,42 & 3,02 & 1,62 \\
\hline $\begin{array}{l}\text { Fosfato bicálcico }(\%) \\
\text { Dicalcium phosphate }\end{array}$ & 2,20 & 2,60 & 3,00 \\
\hline $\begin{array}{l}\text { Cloreto de sódio }(\%) \\
\text { Sodium chloride }\end{array}$ & 2,00 & 2,00 & 2,00 \\
\hline $\begin{array}{l}\text { Sulfato de cálcio (\%) } \\
\text { Calcium sulphate }\end{array}$ & 1,67 & 1,67 & 1,67 \\
\hline $\begin{array}{l}\text { Calcário dolomítico }(\%) \\
\text { Dolomite limestone }\end{array}$ & 0,60 & 0,60 & 0,60 \\
\hline $\begin{array}{l}\text { Óxido de magnésio (\%) } \\
\text { Magnesium oxide }\end{array}$ & 0,50 & 0,50 & 0,50 \\
\hline $\begin{array}{l}\text { Melaço de cana em pó (\%) } \\
\text { Powdered sugar cane juice }\end{array}$ & 0,50 & 0,50 & 0,50 \\
\hline $\begin{array}{l}\text { Sulfato de cobre }(\mathrm{mg} / \mathrm{kg}) \\
\text { Copper sulphate }\end{array}$ & 243,00 & 243,00 & 243,00 \\
\hline $\begin{array}{l}\text { Óxido de zinco }(\mathrm{mg} / \mathrm{kg}) \\
\text { Zinc oxide }\end{array}$ & 150,00 & 150,00 & 150,00 \\
\hline $\begin{array}{l}\text { Sulfato ferroso }(\mathrm{mg} / \mathrm{kg}) \\
\text { Iron sulphate }\end{array}$ & 96,00 & 96,00 & 96,00 \\
\hline $\begin{array}{l}\text { Sulfato de manganês }(\mathrm{mg} / \mathrm{kg} \\
\text { Magnesium sulphate }\end{array}$ & ) 89,00 & 89,00 & 89,00 \\
\hline $\begin{array}{l}\text { B.H.T. }{ }^{1}, \mathrm{mg} / \mathrm{kg} \\
\text { Sulfato de cobalto }(\mathrm{mg} / \mathrm{kg})\end{array}$ & $\begin{array}{l}48,00 \\
32,00\end{array}$ & $\begin{array}{l}48,00 \\
32,00\end{array}$ & $\begin{array}{l}48,00 \\
32,00\end{array}$ \\
\hline $\begin{array}{l}\text { Cobalt sulphate } \\
\text { Iodato de cálcio }(\mathrm{mg} / \mathrm{kg}) \\
\text { Calcium iodate }\end{array}$ & 8,00 &, 00 & 8,00 \\
\hline $\begin{array}{l}\text { Sulfato de cromo }(\mathrm{mg} / \mathrm{kg}) \\
\text { Chromium sulphate }\end{array}$ & 6,00 & 6,00 & 6,00 \\
\hline $\begin{array}{l}\text { Selenito de sódio }(\mathrm{mg} / \mathrm{kg}) \\
\text { Sodium selenate }\end{array}$ & 1,00 & 1,00 & 1,00 \\
\hline $\begin{array}{l}\text { Niacina }(\mathrm{mg} / \mathrm{kg}) \\
\text { Niacin }\end{array}$ & 400,00 & 400,00 & 400,00 \\
\hline $\begin{array}{l}\text { Vitamina } \mathrm{A}(\mathrm{UI} / \mathrm{kg}) \\
\text { Vitamin A }\end{array}$ & 8000,00 & 8000,00 & 8000,00 \\
\hline $\begin{array}{l}\text { Vitamina } \mathrm{E}(\mathrm{UI} / \mathrm{kg}) \\
\text { Vitamin } E\end{array}$ & 8,00 & 8,00 & 8,00 \\
\hline
\end{tabular}

${ }^{1}$ B.H.T. - antioxidante (antioxidant). 
lactantes, foram selecionadas por toque retal. Esses animais foram divididos em três grupos de 22 receptoras colocadas em piquetes de Braquiaria decumbens e receberam $1,25 \mathrm{~kg}$ de concentrado/ cabeça/dia com três diferentes tipos, nos quais variava a fonte protéica, sendo ofertado às $8 \mathrm{~h} 30$ e $16 \mathrm{~h} 30$. Após a adaptação, os animais permaneceram na mesma dieta até o fim do experimento.

$\mathrm{O}$ grupo $\mathrm{S}$ tinha como fonte protéica somente o farelo de soja. $\mathrm{O}$ grupo $\mathrm{S}+\mathrm{U}$ teve a metade de sua proteína fornecida pelo farelo de soja, sendo o restante

Tabela 2 - Análise bromatológica dos suplementos concentrados usados nas dietas das doadoras de embriões

Table 2 - Concentrate supplement analysis used in embryo donors diets

\begin{tabular}{|c|c|c|c|}
\hline $\begin{array}{l}\text { Concentrados } \\
\text { Concentrate }\end{array}$ & $\begin{array}{l}\text { Soja } \\
\text { Soya }\end{array}$ & $\begin{array}{c}\text { Soja+Uréia } \\
\text { Soya+Urea } \\
(\%)\end{array}$ & $\begin{array}{l}\text { Uréia } \\
\text { Urea }\end{array}$ \\
\hline $\begin{array}{l}\text { Proteína bruta } \\
\text { Crude protein }\end{array}$ & 19,92 & 21,14 & 24,75 \\
\hline $\begin{array}{l}\text { Nutrientes digestíveis } \\
\text { totais (Estimado) } \\
\text { Total digestible nutrients } \\
\text { (estimated) }\end{array}$ & 68,50 & 68,00 & 68,00 \\
\hline $\begin{array}{l}\text { Matéria seca } \\
\text { Dry matter }\end{array}$ & 90,39 & 90,85 & 91,60 \\
\hline $\begin{array}{l}\text { Fibra em detergente neutro } \\
\text { Neutral detergent fiber }\end{array}$ & 22,53 & 23,40 & 18,19 \\
\hline $\begin{array}{l}\text { Fibra em detergente ácido } \\
\text { Acid detergent fiber }\end{array}$ & 12,77 & 11,06 & 7,63 \\
\hline $\begin{array}{l}\text { Cálcio } \\
\text { Calcium }\end{array}$ & 2,71 & 1,82 & 2,79 \\
\hline $\begin{array}{l}\text { Fósforo } \\
\text { Phosphorus }\end{array}$ & 1,35 & 0,86 & 1,24 \\
\hline
\end{tabular}

Tabela 3 - Composição do sal mineral usado na suplementação ad libitum das doadoras e receptoras de embriões

Table 3 - Mineral salt composition used in ad libitum supplementation of embryo donors and recipients

\begin{tabular}{lc}
\hline Elemento & $\begin{array}{c}\text { Quantidade } \\
\text { Quantity }\end{array}$ \\
\hline Element & 142,60 \\
Cálcio (Calcium), g/kg & 84,93 \\
Fósforo (Phosphorus), g/kg & 13,02 \\
Magnésio (Magnesium), g/kg & 11,88 \\
Enxofre (Sulfur), g/kg & 0,02 \\
Potássio (Potassium), g/kg & 8877,00 \\
Manganês (Manganese), $\mathrm{mg} / \mathrm{kg}$ & 1865,00 \\
Zinco (Zinc), mg/kg & 1251,00 \\
Ferro (Iron), $\mathrm{mg} / \mathrm{kg}$ & 1181,00 \\
Sódio (Sodium), $\mathrm{mg} / \mathrm{kg}$ & 15,00 \\
Cobre (Copper), $\mathrm{mg} / \mathrm{kg}$ &
\end{tabular}

R. Bras. Zootec., v.32, n.1, p.77-84, 2003 substituído por uréia $(62,5 \mathrm{~g})$, enquanto o grupo U possuía apenas uréia $(125 \mathrm{~g})$. A composição e a análise bromatológica dos concentrados oferecidos às receptoras estão nas Tabelas 4 e 5 .

A formulação foi efetuada atendendo às exigências fornecidas pelo NRC (1996), para animais com peso médio de $400 \mathrm{~kg}$, consumo de matéria seca de $2,15 \%$ do peso vivo e para um ganho de peso de $453 \mathrm{~g} / \mathrm{dia}$.

No dia da entrada dos animais e a cada 40 dias foi colhida amostra de pastagem para determinação de sua composição e da disponibilidade de matéria seca, num total de quatro amostras. Essa amostragem foi feita com um retângulo de meio metro quadrado que era arremessado por nove vezes na área a ser amostrada, em cada amostragem. Toda a pastagem disponível acima de cinco $\mathrm{cm}$ era recolhida, pesada e uma amostra era destinada a análise bromatológica.

Para se obter embriões para descongelamento e inovulação na estação seca, foram efetuadas colheitas de embriões em vacas e novilhas doadoras da raça holandesa, recuperando-se um total de $77 \mathrm{em}$ briões. Optou-se por usar o método de descongelamento direto ou "One-Step". A desidratação foi efetuada em etilenoglicol $1.5 \mathrm{M}$ com tampão Zwitterionic (Encare $\left.{ }^{\circledR}, \mathrm{ICP}\right)$, por 10 minutos.

Para o congelamento utilizou-se um congelador automático (Freeze-Control 5000) com seeding a $-6^{\circ} \mathrm{C}$, equilíbrio por 10 minutos, descida de $0,5^{\circ} \mathrm{C}$ por minuto até $-32^{\circ} \mathrm{C}$, novo equilíbrio de 10 minutos e em seguida imersão em nitrogênio líquido.

Os cios das receptoras foram sincronizados com aplicação única de $150 \mu \mathrm{g}$ de cloprostenol (Veteglan ${ }^{\circledR}$, Calier). A cada aplicação, as receptoras que eram observadas em cio foram avaliadas por intermédio de ultra-sonografia e inovuladas seis a oito dias mais tarde através de técnica transcervical. $\mathrm{O}$ descongelamento dos embriões foi efetuado no ar por cinco segundos, seguido de imersão em água entre 22 e $24^{\circ} \mathrm{C}$, por 20 segundos.

Para avaliação da taxa de reabsorção embrionária e de prenhez, foi efetuada avaliação ultrasonográfica transretal nas receptoras aos 30 e 60 dias da suposta gestação, com aparelho de ultra-som, modelo Scanner 100 LC VET (Pie Medical), com transdutor linear $6 / 8 \mathrm{MHz}$.

Delineamento experimental e análise estatística

Nos experimentos I e II foram utilizados os delineamentos inteiramente casualizados. Os dados foram submetidos à análise de variância com procedimento GLM (Statistical Analysis System, 1991). Nas 
Tabela 4 - Composição dos suplementos concentrados usados nas dietas das receptoras de embriões

Table 4 - Concentrate supplement composition used in embryo recipients diets

\begin{tabular}{|c|c|c|c|}
\hline $\begin{array}{l}\text { Ingredientes } \\
\text { Ingredients }\end{array}$ & $\begin{array}{l}\text { Soja } \\
\text { Soya }\end{array}$ & $\begin{array}{r}\text { Soja }+ \text { Uréi } \\
\text { Soya }+ \text { Urec }\end{array}$ & $\begin{array}{ll}\text { a Uréia } \\
\text { a } & \text { Urea } \\
\end{array}$ \\
\hline Farelo de soja (\%) & 76,80 & 38,40 & 0,00 \\
\hline $\begin{array}{l}\text { Soybean meal } \\
\text { Uréia pecuária (\%) }\end{array}$ & 0,00 & 5,00 & 10,00 \\
\hline Urea & & & \\
\hline $\begin{array}{l}\text { Milho integral moído (\%) } \\
\text { Milled maize }\end{array}$ & 10,00 & 45,99 & 81,97 \\
\hline $\begin{array}{l}\text { Caulim }(\%) \\
\text { Clay }\end{array}$ & 6,27 & 3,14 & 0,00 \\
\hline $\begin{array}{l}\text { Fosfato bicálcico }(\%) \\
\text { Dicalcium phosphate }\end{array}$ & 1,55 & 2,32 & 3,10 \\
\hline $\begin{array}{l}\text { Cloreto de sódio }(\%) \\
\text { Sodium chloride }\end{array}$ & 2,00 & 2,00 & 2,00 \\
\hline $\begin{array}{l}\text { Sulfato de cálcio }(\%) \\
\text { Calcium sulphate }\end{array}$ & 1,67 & 1,67 & 1,67 \\
\hline $\begin{array}{l}\text { Calcário dolomítico }(\%) \\
\text { Dolomite limestone }\end{array}$ & 0,60 & 0,30 & 0,00 \\
\hline $\begin{array}{l}\text { Óxido de magnésio }(\%) \\
\text { Magnesium oxide }\end{array}$ & 0,50 & 0,58 & 0,65 \\
\hline $\begin{array}{l}\text { Melaço de cana em pó (\%) } \\
\text { Powdered sugar cane juice }\end{array}$ & 0,50 & 0,50 & 0,50 \\
\hline $\begin{array}{l}\text { Sulfato de cobre }(\mathrm{mg} / \mathrm{kg}) \\
\text { Coppersulphate }\end{array}$ & 243,00 & 243,00 & 243,00 \\
\hline $\begin{array}{l}\text { Óxido de zinco }(\mathrm{mg} / \mathrm{kg}) \\
\text { Zinc oxide }\end{array}$ & 150,00 & 150,00 & 150,00 \\
\hline $\begin{array}{l}\text { Sulfato ferroso }(\mathrm{mg} / \mathrm{kg}) \\
\text { Iron sulphate }\end{array}$ & 96,00 & 96,00 & 96,00 \\
\hline $\begin{array}{l}\text { Sulfato de manganês }(\mathrm{mg} / \mathrm{kg}) \\
\text { Manganese sulphate }\end{array}$ & 89,00 & 89,00 & 89,00 \\
\hline B.H.T. ${ }^{1}(\mathrm{mg} / \mathrm{kg})$ & 48,00 & 48,00 & 48,00 \\
\hline $\begin{array}{l}\text { Sulfato de cobalto }(\mathrm{mg} / \mathrm{kg}) \\
\text { Cobalt sulphate }\end{array}$ & 32,00 & 32,00 & 32,00 \\
\hline $\begin{array}{l}\text { Iodato de cálcio }(\mathrm{mg} / \mathrm{kg}) \\
\text { Calcium iodate }\end{array}$ & 8,00 & 8,00 & 8,00 \\
\hline $\begin{array}{l}\text { Sulfato de cromo }(\mathrm{mg} / \mathrm{kg}) \\
\text { Chromo sulphate }\end{array}$ & 6,00 & 6,00 & 6,00 \\
\hline $\begin{array}{l}\text { Selenito de sódio }(\mathrm{mg} / \mathrm{kg}) \\
\text { Sodium selenate }\end{array}$ & 1,00 & 1,00 & 1,00 \\
\hline $\begin{array}{l}\text { Niacina }(\mathrm{mg} / \mathrm{kg}) \\
\text { Niacin }\end{array}$ & 400,00 & 400,00 & 400,00 \\
\hline $\begin{array}{l}\text { Vitamina } \mathrm{A}(\mathrm{UI} / \mathrm{kg}) \\
\operatorname{Vitamin} A\end{array}$ & 8000,00 & 8000,00 & 8000,00 \\
\hline $\begin{array}{l}\text { Vitamina } \mathrm{E}(\mathrm{UI} / \mathrm{kg}) \\
\text { Vitamin E }\end{array}$ & 8,00 & 8,00 & 8,00 \\
\hline
\end{tabular}

${ }^{1}$ B.H.T. antioxidante (antioxidant).

doadoras também foram usados para confirmação dos resultados, a análise de variância para o teste de medianas de Kruskal-Wallis e o de Mann-Whitney U (Statsoft, 1995). As variáveis percentagens de embriões viáveis, de não fecundados e de embriões degenerados, bem como a taxa de eclosão de embriões in vitro foram transformadas em raiz quadrada. $\mathrm{O}$ nível de significância foi estabelecido em $5 \%$.
Tabela 5 - Análise bromatológica dos suplementos concentrados usados nas dietas das receptoras de embriões

Table 5 - Concentrate supplement analisys used in embryo recipients diets

\begin{tabular}{|c|c|c|c|}
\hline $\begin{array}{l}\text { Análise } \\
\text { Analysis }\end{array}$ & $\begin{array}{l}\text { Soja } \\
\text { Soya }\end{array}$ & $\begin{array}{c}\text { Soja + Uréia } \\
\text { Soya }+ \text { Urea } \\
(\%)\end{array}$ & $\begin{array}{l}\text { Uréia } \\
\text { Urea }\end{array}$ \\
\hline $\begin{array}{l}\text { Proteína bruta } \\
\text { Crude protein }\end{array}$ & 31,72 & 32,06 & 32,37 \\
\hline $\begin{array}{l}\text { Nutrientes digestíveis } \\
\text { totais (Estimado) } \\
\text { Total digestible nutrients } \\
\text { (estimated) }\end{array}$ & 66,00 & 66,00 & 66,00 \\
\hline $\begin{array}{l}\text { Matéria seca } \\
\text { Dry matter }\end{array}$ & 94,19 & 92,61 & 91,91 \\
\hline $\begin{array}{l}\text { Fibra em detergente neutro } \\
\text { Neutral detergent fiber }\end{array}$ & 44,17 & 28,93 & 25,74 \\
\hline $\begin{array}{l}\text { Fibra em detergente ácido } \\
\text { Acid detergent fiber }\end{array}$ & 19,78 & 12,40 & 3,06 \\
\hline $\begin{array}{l}\text { Cálcio } \\
\text { Calcium }\end{array}$ & 1,88 & 2,54 & 2,38 \\
\hline $\begin{array}{l}\text { Fósforo } \\
\text { Phosphorus }\end{array}$ & 0,88 & 1,13 & 1,25 \\
\hline
\end{tabular}

\section{Resultados e Discussão}

Experimento I: Uréia na alimentação de doadoras de embriões

Os dados das colheitas de embriões e do cultivo in vitro nos grupos $\mathrm{S}, \mathrm{S}+\mathrm{U}$ e $\mathrm{U}$ são apresentados na Tabela 6 .

Os resultados não mostraram diferenças $(\mathrm{P}>0,05)$ em nenhum dos aspectos analisados. O número de embriões totais foi de 4,$17 ; 8,42$ e 7,00 , respectivamente, para $\mathrm{S}, \mathrm{S}+\mathrm{U}$ e $\mathrm{U}$, mostrando valores absolutos maiores nos grupos $\mathrm{S}+\mathrm{U}$ e $\mathrm{U}$, o mesmo acontecendo com o número de embriões viáveis $(2,25 ; 3,50$ e 4,33) e com o número de embriões eclodidos $(1,83 ; 2,75$ e $3,67)$. Estes dados mostram que a resposta superovulatória e a qualidade dos embriões não foram afetadas pela inclusão da uréia. Além disso, a percentagem de embriões viáveis $(54,00 ; 41,58$ e $61,90)$ e de embriões eclodidos $(81,48 ; 78,57 ; 84,62)$ dos grupos $\mathrm{S}, \mathrm{S}+\mathrm{U}$ e $\mathrm{U}$, respectivamente, foram muito semelhantes. Este resultados estão de acordo com os obtidos por Erb et al. (1976), os quais concluíram que o fator principal para se determinar a quantidade de uréia a ser usada na dieta é a forma de administração. Quando usada em uma ração completa, balanceada e misturada, de livre acesso, mesmo em altas quantidades, não provocou danos reprodutivos. 
Tabela 6 - Classificação das estruturas e cultivo in vitro dos embriões obtidos de doadoras submetidas a três diferentes fontes protéicas

Table 6 - Structures classification and in vitro culture of embryos obtained from three different protein sources

\begin{tabular}{lccc}
\hline Lote & Soja & Soja + Uréia & Uréia \\
Group & Soya & Soya + Urea & Urea \\
\hline Colheitas & 12,0 & 12,0 & 12,0
\end{tabular}

Flushings

Total de estruturas

Total of structures

Total de estruturas/ $\quad 4,2 \pm 3,1 \quad 8,4 \pm 9,1 \quad 7,0 \pm 6,6$
Colheita

Total of structures/

Flushings

Embriões viáveis/Colheita 2,2 $\pm 2,1 \quad 3,5 \pm 5,8 \quad 4,3 \pm 4,3$

Viable embryos/Flushing

(\%)

$54,0 \pm 40,6 \quad 41,6 \pm 40,4 \quad 61,9 \pm 41,1$

Não Fecundados $\quad 1,4 \pm 2,5 \quad 3,9 \pm 8,5 \quad 1,1 \pm 1,7$

/Colheita

Oocyte/Flushing

(\%)

$34,0 \pm 28,2 \quad 46,5 \pm 40,1 \quad 15,5 \pm 31,9$

Degenerados/Colheita $\quad 0,5 \pm 1,0 \quad 1,0 \pm 0,8 \quad 1,8 \pm 3,3$

Degenerated/Flushing

$(\%)$

$12,0 \pm 14,2 \quad 11,8 \pm 27,4 \quad 26,2 \pm 30,0$

Embriões eclodidos/ $\quad 1,8 \pm 2,0 \quad 2,7 \pm 5,1 \quad 3,7 \pm 4,1$

colheita

Ecloded embryos/

Flushing

$(\%)^{1} \quad 81,5 \pm 47,7 \quad 78,6 \pm 45,2 \quad 84,6 \pm 46,8$

${ }^{1}$ Calculado sobre o número de embriões viáveis colocados em cultivo.

${ }^{1}$ Calculated with total number of viable embryos cultivated.

Corroborando este argumento, Howard et al. (1987) demonstraram que o livre acesso a uma dieta completamente misturada é um dos fatores responsáveis pela ausência de efeitos deletérios do excesso de proteína sobre a reprodução, como foi o caso do fornecimento da dieta no presente experimento.

Vale salientar que os concentrados testados eram isoenergéticos, o que poderia explicar a diferença em relação a outros trabalhos descritos na literatura, nos quais foram detectados efeitos prejudiciais de dietas hiperprotéicas, em decorrência do desbalanceamento da energia das dietas dos animais envolvidos, levando a alterações no ambiente uterino (Jordan \& Swanson, 1979; Kaim et al., 1983; Canfield et al., 1990).

As vacas doadoras que participaram do experimento não eram lactantes e não estavam em balanço energético negativo, demonstrado pelo ganho de peso durante todo o período experimental. Resultados semelhantes em termos de produção embrionária foram obtidos por Garcia-Bojalil et al. (1994), trabalhando com vacas holandesas não-lactantes e níveis de energia adequados, alimentadas com silagem de milho, feno e concentrados protéicos com 12,3 e 27,4\% de proteína bruta, em dieta totalmente misturada, duas vezes ao dia, com adição de vitaminas A, D3 e E.

Humblot et al. (1998) encontraram na superovulação feita em doadoras submetidas a uma dieta com excesso de energia, três ou menos embriões viáveis, quando comparadas a vacas produzindo mais de seis embriões viáveis em dieta normal, ressaltando que o excesso de energia poderia ser o fator principal de falhas na superovulação.

Elrod \& Butler (1993) sugeriram que animais com dietas contendo alta proteína e com energia restrita não teriam problemas na superovulação, mas a limitação energética da dieta teria efeito mais tardio, apresentando aumento na mortalidade embrionária após 17 dias da concepção. Entretanto, Gath et al. (1999), avaliando a taxa de prenhez aos 35 dias por inseminação artificial com dietas semelhantes às do trabalho anterior, não observaram tais diferenças.

Experimento II: Uréia na alimentação de receptoras de embriões

Um animal do grupo S morreu durante o experimento tendo o grupo ficado com 21 receptoras. As sincronizações de cios, descongelamentos e inovulações foram feitos em quatro momentos diferentes, formando quatro ciclos de sincronização. Durante o primeiro ciclo de sincronização, a taxa de prenhez foi possivelmente influenciada pelo estresse dos animais, que não estavam habituados a manipulação frequente, tendo sido criados de forma extensiva, Ciclo 1: 13,79\% $(n=29)$ vs. Ciclos 2 e $3: 38,71 \%(n=31)$.

Observou-se sensível diminuição da matéria seca disponível na pastagem a partir da segunda amostragem, continuando a queda após a terceira amostragem e prosseguindo até a última(Tabela 7). Além da redução da matéria seca da forragem, houve também queda na proteína bruta e no fósforo da pastagem e aumento da fibra em detergente neutro e ácido. Esta redução do valor nutritivo da pastagem era esperada e retrata fielmente a condição nutricional oferecida na estação seca do Brasil Central. Nos últimos 20 dias, já no mês de outubro, ocorreram as primeiras chuvas, o que causou apodrecimento e perda de grande parte da forragem ainda disponível. Isso pode ter concorrido para uma queda na taxa de prenhez do quarto ciclo de inovulações, Ciclos 2 e 3 : $38,71 \%, \mathrm{n}=31$ vs. Ciclo $4: 11,77 \%, \mathrm{n}=17$. 
Após os exames de ultra-sonografia feitos aos 30 e aos 60 dias de gestação os resultados do diagnóstico de gestação e de reabsorção embrionária ocorridos neste período são mostrados na Tabela 8 .

A taxa de prenhez aos 30 dias foi de 25,28 e $28,57 \%$ e aos 60 dias foi de 16,$67 ; 28$ e $25 \%$, não mostrando diferenças $(\mathrm{P}>0,05)$ entre os grupos $\mathrm{S}$, $\mathrm{S}+\mathrm{U}$ e U, respectivamente. Estes resultados estão de acordo com os obtidos por Thompson et al. (1973), que, trabalhando com inseminação artificial, não encontraram diferenças significativas na taxa de prenhez entre vacas suplementadas com dietas à base de farelo de soja ou uréia.

A forma da suplementação do nitrogênio não protéico e ou da proteína verdadeira, bem como a relação energia:proteína do suplemento e dieta total, deve ser aspecto fundamental para que não haja transtornos reprodutivos também para as vacas recptoras mantidas em pasto, conforme considerações importantes apontadas neste sentido por Erb et al. (1976) e Howard et al. (1987).

Todas as receptoras que participaram do experimento e não confirmaram prenhez foram colocadas em estação de monta de novembro de 1999 a março de 2000. Em maio de 2000, todos os animais foram examinados, por toque retal, para diagnóstico de gestação e tiveram prenhez confirmada, atestando a fertilidade dos mesmos, além de comprovar que o tipo de suplementação utilizada não comprometeu a posterior capacidade reprodutiva dos animais.

Tabela 7 - Análise bromatológica da pastagem das receptoras de embriões Table 7 - Analysis of embryo recipient pasture

\begin{tabular}{|c|c|c|c|c|}
\hline $\begin{array}{l}\text { Amostras } \\
\text { Samples }\end{array}$ & $25 / 06 / 99$ & $05 / 08 / 99$ & $13 / 09 / 99$ & $27 / 10 / 99$ \\
\hline MS disponível nos 45,68 ha (t) & 67,510 & 66,380 & 45,000 & 36,970 \\
\hline $\begin{array}{l}\text { Dry matter available on } 45.68 \text { ha }(t) \\
\text { Proteína bruta }(\%)\end{array}$ & 5,4620 & 4,7350 & 4,1190 & 3,790 \\
\hline $\begin{array}{l}\text { Crude protein } \\
\text { Degradabilidade in vitro (\%) }\end{array}$ & 54,210 & 47,140 & 58,160 & 47,750 \\
\hline $\begin{array}{l}\text { In vitro degradation } \\
\text { Fibra em detergente ácido (\%) } \\
\text { Acid detergent fiber }\end{array}$ & 46,050 & 45,860 & 50,850 & 52,810 \\
\hline $\begin{array}{l}\text { Fibra em detergente neutro }(\%) \\
\text { Neutral detergent fiber }\end{array}$ & 75,850 & 79,610 & 78,230 & 82,580 \\
\hline $\begin{array}{l}\text { Fósforo (\%) } \\
\text { Phosphorus }\end{array}$ & 0,081 & 0,071 & 0,065 & 0,058 \\
\hline
\end{tabular}

Tabela 8 - Taxa de prenhez aos 30 e 60 dias e de reabsorção embrionária em receptoras de embriões, submetidas a três diferentes fontes protéicas

Table 8 - Pregnancy rates at 30 and 60 days and of embryo loss in embryo recipients submited to three different protein sources

\begin{tabular}{lcccc}
\hline $\begin{array}{l}\text { Lote } \\
\text { Group }\end{array}$ & $\begin{array}{c}\text { Número de T.E. } \\
\text { Embryo transfer number }\end{array}$ & $\begin{array}{c}\text { Prenhez aos 30 dias (\%) } \\
\text { 30 days pregnancy rate (\%) }\end{array}$ & $\begin{array}{c}\text { Prenhez aos 60 dias (\%) } \\
\text { 60 days pregnancy rate (\%) }\end{array}$ & $\begin{array}{c}\text { Reabsorção embrionária }(\%) \\
\text { Embryonary reabsortion }(\%)\end{array}$ \\
\hline $\begin{array}{l}\text { Soja } \\
\text { Soya }\end{array}$ & 24 & $6(25,00)$ & $4(16,67)$ & $2(33,33)$ \\
$\begin{array}{l}\text { Soja +Uréia } \\
\text { Soya }+ \text { Urea }\end{array}$ & 25 & $7(28,00)$ & $7(28,00)$ & $0(0,00)$ \\
$\begin{array}{l}\text { Uréia } \\
\text { Urea }\end{array}$ & 28 & $8(28,57)$ & $7(25,00)$ & $1(12,50)$ \\
Total & 77 & $21(27,27)$ & $18(23,38)$ & $3(14,29)$ \\
\hline
\end{tabular}

R. Bras. Zootec., v.32, n.1, p.77-84, 2003 


\section{Conclusões}

A uréia, quando fornecida para vacas Nelore juntamente com uma dieta balanceada em energia, minerais e vitaminas, mostrou-se como uma opção de substituição do farelo de soja em mistura de concentrados para suplementação de doadoras e receptoras de embriões bovinos, sem afetar o seu desempenho reprodutivo nos parâmetros testados.

\section{Agradecimento}

À EMBRAPA Recursos Genéticos e Biotecnologia, EMBRAPA Cerrados, Faculdade de Agronomia e Veterinária da Universidade de Brasília, CAPES, Integral Nutrição Animal, Calier do Brasil, UPIS e ED-VET HD, pelo essencial apoio para realização deste trabalho.

Literatura Citada

ANDRADE, V.J.; AZEVEDO, N.A.; KRASSEL, A.R. et al. Desempenho reprodutivo de vacas holando zebu suplementadas com uréia. Revista Brasileira de Reprodução Animal, v.16, n.161, p.3-4, 1992.

BISHONGA, C.; ROBINSON, J.J.; MCEVOY,. T.G. et al. The effects of excess rumen degradable protein in ewes on ovulation rate. fertilization and embryo survival in vivo and during in vitro culture. Animal Production, v.58, p.447, 1994.

BISHONGA, C.; ROBINSON, J.J.; MCEVOY, T.G. et al. Excess dietary urea intake and its effects on ovulation rate and embryo development. Japonese Journal Veterinary Research, v.44, n.3, p.139, 1996.

CANFIELD, R.W.; SNIFFEN, C.J.; BUTLER, W.R. Effects of excess degradable protein on pastpartum reproduction and energy balance in dairy cattle. Journal of Dairy Science, v.73, p.2342, 1990.

CARROLL, D.J.; BARTON, B.A.; ANDERSON, G.W. et al. Influence of protein intake and feeding strategy on reproductive performance of dairy cows. Journal of Dairy Science, v.71, p.3470, 1988.

DASGUPTA, P.R.; KAR, A.B.; DHAR, M.L. Spermicidal activity of urea. Indian Journal of Experimental Biology, v.9, p.414, 1971.

DIXON, R.M.; DOYLE, P.T. A users guide to drought feeding alternatives. Eds J. Rowe and N. Cossins. Armindale: New England, 1996. 61p.

ELROD, C.C.; BUTLER, W.R. Reduction of fertility and alteration of uterine $\mathrm{pH}$ in heifers fed excess ruminally degradable protein. Journal of Animal Science, v.71, p.694, 1993.

ELROD, C.C.; Van AMBURGH, M.; BUTLER, W.R. Alterations of $\mathrm{pH}$ in response to increased dietary protein in cattle are unique to the uterus.Journal of Animal Science v.71, p.702, 1993.

ENRIGHT, W.J.; QUIRKE, J.F.; GLUCKMAN, P.D. et al. Effects of long term administration of pituitary-derived bovine growth hormone and estradiol on growth in steers. Journal of Animal Science, v.68, p.2345, 1990.
ERB, R.E.; BROWN, C.M.; CALLAHAN JR., C.J. et al. Dietary urea for dairy cattle: II. Effect on functional traits. Journal of Dairy Science, v.59, p.656, 1976.

FERGUSON, J.D.; CHALUPA, W. Symposium: interactions of nutrition and reproduction. Impact of protein nutrition on reproduction in dairy cows. Journal of Dairy Science, v.72, p.746, 1989.

FERGUSON, J.D.; GALLIGAN, D.T.; BLANCHARD, T. Blood urea nitrogen and conception rate: usufullness of test information. Journal of Dairy Science, v.74, n.1, p.242, 1991.

FERGUSON, J.D.; GALLIGAN, D.T.; BLANCHARD, T. et al. Serum urea nitrogen and conception rate: The usefulness of test information. Journal of Dairy Science, v.76, p.3742, 1993.

GARCIA-BOJALIL, C.M.; STAPLES, C.R.; THATCHER, W.W. Protein intake and development of ovarian follicles and embryos of superovulated nonlactating dairy cows. Journal Dairy Science, v.77, p.2537, 1994.

GATH, V.; LONERGAN, P.; BOLAND, M.P. et al. Effects of diet type on establishment of pregnancy and embryo development in beef heifers. Theriogenology, v.51, p.224, 1999.

HOWARD, H.J.; AALSETH, E.P.; ADAMS, G.D. et al. Influence of dietary protein on reproductive performance of dairy cow. Journal of Dairy Science, v.70, p.1563,1987.

HUMBLOT, P.; NEGRÃO, S.; MARIE, M. et al. Relationship between diet content, metabolic status and embryo production following superovulation in prim holstein dairy cattle. Journal of Reproduction and Fertility, v.20, p.24, 1998.

JORDAN, E.R.; CHAPMAN, T.E.; HOLTAN, D.W. et al. Relationship of dietary crude protein to composition of uterine secretions and blood in high-producing postpartum dairy cows. Journal of Dairy Science, v.66, p.1854, 1983.

JORDAN, E.R.; SWANSON, D.W. Effect of crude protein on reproductive efficiency. serum total protein and albumin in the high-producing dairy cow. Journal of Dairy Science, v.62, p.58, 1979.

KAIM, M.; FOLMAN, Y.; NEUMARK, H. The effect of protein intake and lactation number on pospartum weight loss and reproductive performance of dairy cows. Animal Production, v.37, p.229, 1983.

NATIONAL RESEARCH COUNCIL - NRC. Nutrients requeriments of beef cattle. Washinghton, National Academy of Science, 1996. 242p.

SHIMBAYASHI, K.; OBARA, Y. Some aspects of urea feeding in ruminants. JARQ, v.21, n.4, p.291,1988.

STALHEIM, O.H.V.; GALLAGHER, J.E. Urea-plasmal epithelial lesions related to ammonia. Infection Immunology, v.15, p.995, 1977.

STATISTICAL ANALYSIS SYSTEM Users Manual, Inc. Cary, Indiana, 1991, $695 \mathrm{p}$.

STATSOFT INC., Statistica for Windows, Computer program manual, Tulsa, OK, 1995.

STRINGFELLOW, D.A.; SEIDEL, S.M. Manual da Sociedade Internacional de Transferência de Embriões. 3.ed., 1999. $180 \mathrm{p}$.

THOMPSON, L.H.; GOODE, L.; HARVEY, R.W. et al. Effects of dietary urea on reproduction in ruminants. Journal of Animal Science, v.37, n.2, p.399, 1973.

R. Bras. Zootec., v.32, n.1, p.77-84, 2003

Recebido em: 27/04/01

Aceito em: 30/08/02 